Accepted for publication in the "Patterns of Social Entrepreneurship Research" book to be published by Edward Elgar in Spring 2012

\title{
Is Social Entrepreneurship Transformational Leadership in Action?
}

By

Divya Bhutiani ${ }^{1}$, Kimberly Flicker ${ }^{2}$, Padmakumar Nair ${ }^{2}$ and Aard Groen ${ }^{1}$

${ }^{1}$ NIKOS, University of Twente, The Netherlands and ${ }^{2}$ University of Texas at Dallas, USA

\section{Executive Summary}

As the title indicates we started with this question with a view to understand how research findings in these two fields of study, social entrepreneurship and transformational leadership, can help groom transformational leaders. It has been argued persuasively by leadership scholars that transformational leaders are essential to building sustainable organizations which consistently create wealth and contribute to the wellbeing of its employees. Even though the importance of transformational leadership in organizations is gaining more and more acceptance among both practitioners and scholars, most organizations still practice a transactional work style. These transactional work environments are not conducive for developing transformational leaders and therefore in this paper we suggest that letting aspiring leaders to get involved in social entrepreneurial ventures is an effective way to groom future transformational leaders.

In this research we explored and uncovered the relationship between social entrepreneurship and transformational leadership for the following two purposes: First, to 
help social entrepreneurship researchers learn from the transformational leadership literature. Compared to social entrepreneurship research, the field of transformational leadership has reached a certain level of maturity so that social entrepreneurship researchers can borrow proven research methodologies and ideas from it. Secondly, we use this knowledge to develop strategies for instilling transformational leadership skills in students and practitioners aspiring to become transformational leaders. We have developed a framework to compare the conceptual basis of both social entrepreneurship and transformational leadership. We have also tried to explore the similarities between the processes of social-entrepreneuring and transformational-leading using this framework. Additionally, we have used the framework to study three of the most famous social entrepreneur turned transformational leaders of our time: Mother Teresa, Mahatma Gandhi and Wangari Maathai. We propose that helping people to experience social entrepreneuring is an effective way to instill transformational leadership skills.

\section{Introduction}

Leadership and Entrepreneurship are two fields of research that many researchers feel have faced similar conceptual and methodological challenges. Both have faced definitional conflicts in the sense that individual researchers have tried to define each of them differently (Avolio et al., 2003; Yukl, 2002; Shane \& Venkataraman, 2000). Both have faced measurement issues in the sense that there are challenges related to scale development and application of analysis tools for performing empirical research (Antonakis et al., 2004b; Low \& MacMillan, 1988; Vecchio, 2003; Wortman, 1987). 
So far, a considerable amount of research has been completed investigating the relationship between entrepreneurship and leadership (Schumpeter, 1934; Vecchio, 2003; Cogliser \& Brigham, 2004). Cogliser and Brigham (2004) published a remarkable piece of research on the intersection between leadership and entrepreneurship by selecting four constructs on which the two fields appear to converge-vision, influence, creativity and planning. In addition, many other researchers have defined entrepreneurship in terms of leadership. Schumpeter (1934) defined the role of an entrepreneur as, “... another form of individual leadership acting by virtue of personal force and personal responsibility for success.” Vecchio (2003) introduced an entrepreneurial leadership model to discuss various stages of firm development.

Literature also shows evidence of research involving transformational leadership and entrepreneurship (Bass, 1985; Conger \& Kanungo, 1998; Cogliser \& Brigham, 2004; Eyal \& Kark, 2004; Ensley et.al., 2006; and Matzler et.al., 2008). Matzler et. al. (2008) in a recent article noted a positive relationship between transformational leadership and innovation as one of the primary characteristics of entrepreneurs (Schumpeter, 1934; Drucker, 1985; McDaniel, 2000; Johnson, 2001) indirectly creating the linkage between transformational leadership and entrepreneurship. Ensley et al. (2006) in a study performed on top management teams of new entrepreneurial ventures investigated the impact of different styles of leadership on the entrepreneurial success of those companies. They found that shared transformational leadership is positively related to entrepreneurial 
performance in contrast to vertical transformational leadership. Eyel \& Kark’s study in 2004 showed that transformational leadership plays a great role in radical entrepreneurship for both profit and non-profit organizations. Congo \& Kanungo (1998) characterize transformational leaders to be change oriented and entrepreneurial by nature. Cogliser \& Brigham (2004), as mentioned above, discussed the mutual lessons the two fields of leadership and entrepreneurship need to learn from each other stressing that both transformational leadership and entrepreneurship rely on the leader’s vision to produce successful results. Bass (1985) in his book, “Leadership and performance beyond expectations”, highlights the deep impact transformational leaders leave on the followers through affecting their motivational and performance levels at work.

However, to the best of our knowledge, no research has been conducted highlighting the overlap between social entrepreneurship and transformational leadership. Over the past few decades, social entrepreneurship, as a research domain, has grown in importance. Best exemplified by the plethora of popular and scholarly books written exclusively about social entrepreneurship. With this observation in mind, we attempt to uncover the relationship between social entrepreneurship and transformational leadership to explore how social entrepreneurship researchers can benefit from the concepts, tools and methods used in leadership research in general and transformational leadership in particular and to develop strategies for instilling transformational leadership skills in students and practitioners through helping them participate in social entrepreneurial ventures. We use case examples of three highly admired and popular personalities across 
the globe to exemplify the overlap between social entrepreneurship and transformational leadership.

\section{Transformational Leadership}

The concept of transformational leadership captured the attention of both scholars and practitioners alike with the publication of Burns' famous book on leadership (Burns, 1978). Burns used the term transforming leadership to describe the behavior of political leaders to demonstrate how they made transformational changes in societies through extraordinary leadership. Later Bass and others developed the idea further resulting in ample evidence exemplifying the role and importance of transformational leaders in creating effective and sustainable organizations (Bass, 1999; Yukl, 1999; Pillai \& Williams, 2003; Roberts, 1985; Zhu, et.al, 2011) and their contribution towards innovative management and leadership practices (Matzler et.al., 2008). Bass (1999) noted how transformational leaders enhance follower's maturity level, concern for others beyond self-interests and consideration for the organization and the society.

Transformational leadership improves organizational performance by increasing group productivity and commitment through enhancing employee self-efficacy and cohesiveness (Pillai \& Williams, 2003). Transformational leadership also strongly contributes towards fostering moral behavior in followers as compared to transactional leadership which has very little long term impact (Zhu, et.al., 2011). According to Roberts (1985), transformational leadership is a collective process in which the 
transformational leader acts as a skillful change agent and empowers the followers by redefining the organization's mission and vision.

\section{Social Entrepreneurship}

While the scholarly discipline of social entrepreneurship is relatively young, the phenomenon itself is not. As noted by Bornstein, (2004) social entrepreneurs have long existed but only recently has their presence and recognition been on the rise. Over the past few decades, social entrepreneurship, has gained increasing interest amongst practitioners, academicians and researchers globally (Alvord et al., 2004; Austin et al., 2006; Dees, 1998). Specifically, a close look at the statistics by the National Centre for Charity reveals the number of registered nonprofit organizations has shown an increase of almost 48 percent from 1995 to 2011 in the United States (National Centre for Charitable Statistics, 2011). Additionally, social entrepreneurship is included in the curriculum of almost every leading business school (Peredo \& Mc Lean, 2005; Byrne, 2010; US News, 2011) and some schools also offer a master's degree (Guttenplan, 2011) or fellowship in this discipline (Harvard Business School). Almost every leading business school has organized at least one conference related to this in the last five years (Baker, Britt., 2010). The popularity of this research domain is also evidenced due to the Academy of Management’s Entrepreneurship division maintaining one award titled, “Best Social Entrepreneurship Paper" (sponsored by Rowan University) out of the eleven ENT awards. In addition, the 2012 special issue of Academy of Management Learning and Education is also dedicated to social entrepreneurship (AOM- ENT Division). 
Similar to entrepreneurship, the construct of social entrepreneurship has also been defined differently by various researchers. One school of thought associates social entrepreneurship with not-for-profit organizations (Austin et.al., 2003; Boschee, 1998) while others associate it only with not-for-profit organizations masquerading as for-profit (Reis, 1999). A third school of thought refers social entrepreneurship to any business venture that wants to contribute towards social well-being. Many scholars (Dees, 1998; Sullivan Mort et al., 2003) suggest that social mission is explicit and central to the mission of social entrepreneurial ventures. In addition, Dees (1998) argues that similar to commercial entrepreneurs, whose mission is to create economic value, social entrepreneurs create sustainable social value. Austin and co-researchers (2006) have defined "social entrepreneurship as an innovative, social value creating activity that can occur within or across the not-for-profit, business, or government sectors” and have tried to distinguish it from commercial entrepreneurship in terms of four variables-market failure, mission, resource mobilization and performance measurement. According to Mair \& Marti (2004), “Social Entrepreneurship is defined as the innovative use of resources to explore and exploit opportunities that meet a social need in a sustainable manner.” David Bornstein (2004) in his book titled, 'How to change the world' has described social entrepreneurs as "change agents” who serve large markets with limited resources. Alvord et.al. (2004) defined social entrepreneurs as individuals who are catalysts for social transformation. Additionally, entrepreneurship researchers have attempted to study the personality characteristics of the social entrepreneurs. The prominent researchers being Drayton (2002), who talked about some special traits possessed by social entrepreneurs, 
while Bornstein (1998) stressed on passionate and strong ethical behavior of social entrepreneurs. Henton, Melville \& Walesh (1997) and Thompson et al., (2000) highlighted the special leadership skills possessed by the social entrepreneurs compared to commercial entrepreneurs. The goals of social entrepreneurs is to effect social change and social transformation; be able to effectively do this with limited resources; and show unique leadership behaviors so that people believe in their vision and follow their passion. The majority of the definitions of social entrepreneurship are at the micro level but in this research article we attempt to offer a working definition of social entrepreneurship at the macro level. According to us, social entrepreneurship is the process of effecting sustainable social change through founding new and innovative enterprises under severe resource constraints primarily for the purpose of creating social value.

\section{Intersection of Social Entrepreneurship and Transformational Leadership}

We use a framework, called the 4I, to study the overlap between social entrepreneurship and transformational leadership (refer Figure 1). The first "I" stands for inspiration defined as, what inspires the social entrepreneur or transformational leader. The second "I" stands for influence defined as, how the social entrepreneur or transformational leader influences their stakeholders or followers. The third "I" is innovation defined as, how the social entrepreneur or transformational leader creates economic or social value. Finally we have implementation, defined as how the social entrepreneur or transformational leader makes the mission happen. We show that there are great similarities between 
social entrepreneurs and transformational leaders on these four constructs and this

overlap has far greater implications on how we can develop transformational leadership skills in students and practitioners.

Figure 1

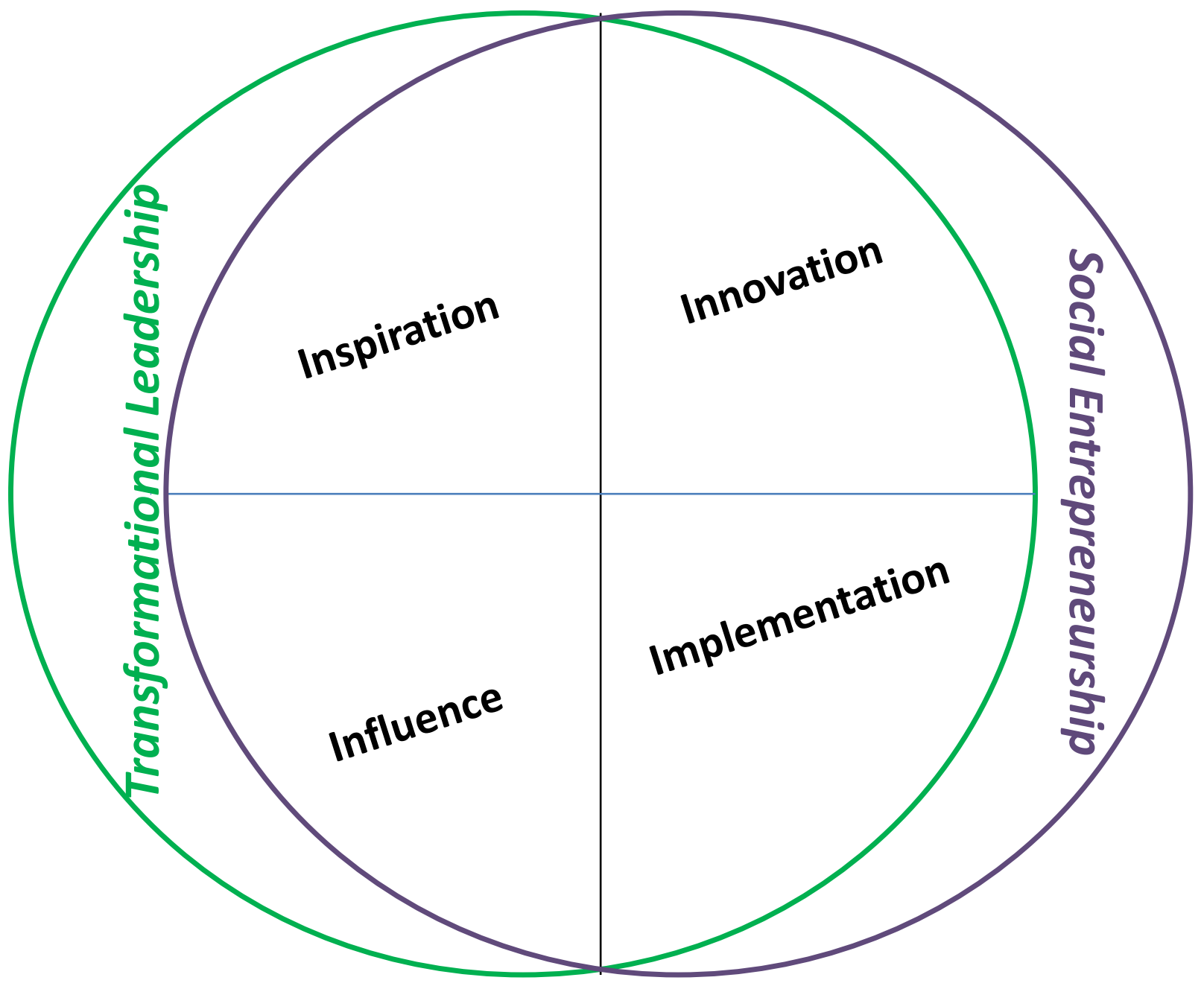

4 I- Framework to study SE \& TL 
Using this framework, we have tabulated the similarities between the two constructs-social entrepreneurship and transformational leadership-to help demonstrate the interrelationships between the two domains of research (Table 1).

\section{Table 1}

Conceptual similarity between social entrepreneurship and transformational leadership

\begin{tabular}{|c|c|c|}
\hline Construct & Social Entrepreneurship & Transformational Leadership \\
\hline $\begin{array}{l}\text { Inspiration } \\
\text { (What inspires the } \\
\text { social } \\
\text { entrepreneur/ } \\
\text { transformational } \\
\text { leader?) }\end{array}$ & $\begin{array}{l}\text { Satisfaction of solving social problems } \\
\text { (Fruchterman, 2011). } \\
\text { Giving meaning to poor person's life (Dees, } \\
\text { 1998). } \\
\text { Improving the lives of the bottom of the } \\
\text { pyramid (Fruchterman, 2011). } \\
\text { Excitement of creating something new. }\end{array}$ & $\begin{array}{l}\text { Nobler goals than immediate profit } \\
\text { (Bass, 1998). } \\
\text { Help others (Bass, 1998). } \\
\text { Connect to as many followers as } \\
\text { possible (Bass, 1998). } \\
\text { Develop others. (Bass, 1998) } \\
\text { Self-Actualization. (Burns, 1978) }\end{array}$ \\
\hline $\begin{array}{l}\text { Influence } \\
\text { (How is the social } \\
\text { entrepreneur/ } \\
\text { transformational } \\
\text { leader influencing } \\
\text { stake }\end{array}$ & $\begin{array}{l}\text { All are agents of change in the social sector } \\
\text { (Dees, 1998) } \\
\text { Reputation for fairness and skill in dealing } \\
\text { with individual needs (Austin, Stevenson, } \\
\text { Wei-Skillern, 2006) } \\
\text { Provide value more explicitly to }\end{array}$ & $\begin{array}{l}\text { Instills pride, gains trust and respect } \\
\text { (Bass, 1998) } \\
\text { Moves followers towards self- } \\
\text { actualization; building enthusiasm } \\
\text { and challenge and meaning. (Burns, } \\
\text { 1978) }\end{array}$ \\
\hline
\end{tabular}




\begin{tabular}{|c|c|c|}
\hline holders/followers?) & $\begin{array}{l}\text { heterogeneous set of stakeholders who look } \\
\text { for distinct form of value (Austin, } \\
\text { Stevenson, Wei-Skillern, 2006) } \\
\text { Strong network of key staff and supporters } \\
\text { who are convinced in value of mission and } \\
\text { organization's capacity to deliver (Austin, } \\
\text { Stevenson, Wei-Skillern, 2006) }\end{array}$ & $\begin{array}{l}\text { Individual considerations such as } \\
\text { personal attention, advice and } \\
\text { coaching allow for development } \\
\text { (Bass, 1998) } \\
\text { Individual treatment follower, yet } \\
\text { fair and just (Bass, 1998) }\end{array}$ \\
\hline $\begin{array}{l}\text { Innovation } \\
\text { (How is the social } \\
\text { entrepreneur/ } \\
\text { transformational } \\
\text { leader creating } \\
\text { social/economic } \\
\text { value?) }\end{array}$ & $\begin{array}{l}\text { Engaging in process to innovate, adapt and } \\
\text { learn (Dees, 1998) } \\
\text { Bold actions, not limited by low resources } \\
\text { (Dees, 1998) } \\
\text { Recognize and pursue opportunities that } \\
\text { serve mission (Dees, 1998) }\end{array}$ & $\begin{array}{l}\text { Intellectual stimulation, expanding } \\
\text { the followers use of their ability, } \\
\text { intelligence, rationality and } \\
\text { problem solving (Bass, 1998) }\end{array}$ \\
\hline $\begin{array}{l}\text { Implementation } \\
\text { (How is the social } \\
\text { entrepreneur/ } \\
\text { transformational } \\
\text { leader making it } \\
\text { happen?) }\end{array}$ & $\begin{array}{l}\text { Adopt mission to create and sustain social } \\
\text { value (Dees, 1998) } \\
\text { Accountability to constituents served and } \\
\text { outcomes created (Dees, 1998) } \\
\text { Theory of change (Colby, Stone \& Carter, } \\
\text { 2004) } \\
\text { Know the industry and known by others for } \\
\text { abilities (Sahlman, 1996; Hart, Stevenson }\end{array}$ & $\begin{array}{l}\text { Clarifies purpose and articulates } \\
\text { mission and vision } \\
\text { Uses symbols to focus efforts } \\
\text { (Bass, 1998) } \\
\text { Communicates high expectations } \\
\text { (Bass, 1998) } \\
\text { Expresses important purposes in } \\
\text { simple ways (Bass, 1998) }\end{array}$ \\
\hline
\end{tabular}




\begin{tabular}{|l|l|l|}
\hline & and Dial 1996) & \multicolumn{1}{|c|}{ Individually considerate, supports, } \\
Robust network of contacts that will provide & $\begin{array}{l}\text { mentors and coaches the follower } \\
\text { access to funding, board members, } \\
\text { management and staff (Austin, Stevenson, }\end{array}$ & $\begin{array}{l}\text { Direct followers out of crisis (Bass, } \\
\text { Wei-Skillern, 2006) }\end{array}$ \\
\hline
\end{tabular}

\section{Inspiration}

The key question here is what motivates or inspires transformational leaders and social entrepreneurs. Burns (1978) noted that transformational leaders are motivated by a desire to become self-actualized. Bass (1998) on the other hand suggested that inspiration for transformational leaders to act might be to develop others, which we might extend into doing good to solve problems. Through a social entrepreneurship lens we see the motivating force behind a social entrepreneur is the satisfaction to solve social problems while improving the lives of those at the bottom of the pyramid (Fruchterman, 2011). This satisfaction of creating something new, to the benefit of the social good, helps a social entrepreneur to give meaning to a poor person's life (Dees, 1998) which could be seen as offering a way to self-actualize to the follower. Similarly, both social entrepreneurs and transformational leaders are not inherently concerned with profit, although both are aware of the fact that profit is essential for achieving the goal and being sustainable.

\section{Influence}


When we look at how social entrepreneurs and/or transformational leaders influence their stakeholders and followers respectively, we observe certain similarities. According to Burns (1978), transformational leaders influence followers by moving them towards selfactualization, by building enthusiasm, and by creating challenging and meaningful goals that followers aim to transcend. Bass (1998) describes transformational leaders as influencing their followers by instilling pride in the group and gaining trust and respect from the followers. He stressed that transformational leaders greatly value their followers by giving them personal attention, advice and coaching leading to their personal development, yet the leaders strive to be always fair and just with everyone. Social entrepreneurs influence their stakeholders by motivating them towards the bigger goal. As per Dees (1998), social entrepreneurs draw upon their stakeholder's desires and needs to solve social problems by including the stakeholders as change agents in the social sector of the issue they address. Social entrepreneurs provide value to their diverse group of stakeholders (customers, volunteers, donors, investors, and partners) through addressing their individual needs. This way of dealing with each stakeholder individually fosters a reputation of fairness in dealing with individuals, creating strong networks of key staff and supporters who are believers in the value of the mission and the organization's capacity to deliver (Austin, Stevenson, Wei-Skillern, 2006).

\section{Innovation}


For innovation, the key question at hand is how the social entrepreneur or transformational leader creates economic or social value. The way transformational leaders innovate is actually the manner in which they encourage followers to pursue their intellectual curiosity by stimulating their grey cells. These leaders tend to expand the follower's ideas, thus enhancing their abilities, skills, intelligence, rationality and problem solving capacities (Bass, 1998). Similarly, Dees in his working paper on social entrepreneurship defines social entrepreneurs as, "individuals who recognize opportunities and get engaged in only those processes that serve their mission and help their various stakeholders to innovate, adapt, learn and act boldly even under resource constraints” (Dees, 1998).

\section{Implementation}

Regarding implementation, the key question is how does the social entrepreneur or the transformational leader make things happen. While a social entrepreneur adopts the mission to create and sustain social values among its followers (Dees, 1998), a transformational leader clarifies and articulates the purpose, vision and mission of his organization to the followers (Bass, 1998) which ultimately stimulates action among the followers. A transformational leader communicates high expectations and important tasks to the followers in simple ways using symbols to focus efforts (Bass, 1998), unlike a transactional leader, who is looking for immediate results by using external motivators for his followers. Burns, in his paper, suggests that a transformational leader makes 
things happen by giving individual consideration, support, mentoring and coaching to the followers (Burns, 1978). When the transformational leader directs the followers out of a crisis, many positive outcomes are observed. For example, increased trust in the leader and the capabilities of the team can be achieved (Bass, 1998). Social entrepreneurs are individuals who know their industries and are known by others in the industries for their abilities to perform well (Sahlman, 1996, Hart, Stevenson and Dial, 1996) and be accountable to their constituents and the outcomes they create (Dees, 1998). Social entrepreneurs are known to build a robust network of contacts that will provide them access to funding, board members, management and staff (Austin, Stevenson, WeiSkillern, 2006). This strong network is built similar to how transformational leaders influence their followers. Once part of the network, the social entrepreneur stimulates the various stakeholders to challenge themselves intellectually and adapt to change (Colby, Stone \& Carter, 2004).

\section{Cases on Social Entrepreneur-turned-Transformational Leaders}

To further exemplify the 4I framework, we have selected three famous social entrepreneurs from history across the globe-Mother Teresa, Mahatma Gandhi and Wangari Maathai. All of these three personalities started their struggle or movement alone, but over time they found increasing number of people supporting their social cause- their social entrepreneurial ventures. All of whom ultimately evolved as great transformational leaders with millions of supporters globally. 


\section{Mother Teresa}

Mother Teresa, an extraordinary individual, devoted her entire life to spreading the message of love and sacrifice. She sacrificed her entire life for the poor, needy, sick and homeless. During a 1989 interview with Edward W. Desmond, published in TIME Magazine, she was quoted as saying, "The hunger for love is much more difficult to remove than the hunger for bread”- best exemplifying her beliefs (Desmond, 1989). Mother Teresa has shown extraordinary transformational leadership skills by inspiring millions to follow her path of love, care and sacrifice. Our belief is best exemplified by Mother Teresa’s actions throughout her life demonstrating social entrepreneurship’s power to impart the qualities of transformational leadership in individuals.

Mother Teresa began her career as a school teacher, soon realizing she had a strong desire to improve the lives of the poor around her. She did this through living among them for which she took basic medical training in a hospital in Calcutta, India. The first year of her social work was very eventful; she opened a school in the slums and started helping the poor and the starving but without any financial resources, was forced to beg for clothes and food to feed those individuals. This exemplified Dees’ (1998) social entrepreneur who shows bold actions with limited resources, and she wasconstantly tempted by the worldly pleasures to return to the comfortable life within the convent. Soon she was joined by her first companion in her effort which then grew to a small group of twelve nuns over the next year when they officially established themselves as the Missionaries of Charity. According to Mother Teresa, their mission 
was to care for, "the hungry, the naked, the homeless, the crippled, the blind, the lepers, all those who felt unwanted, unloved, uncared for throughout society, people that have become a burden to the society and are shunned by everyone" (Cydebot, 2011) The social entrepreneurial venture that Mother Teresa started continued to grow over the years. Today, there are branches in 133 countries with over 5000 nuns and 400 brothers (Missionaries of Charity Brothers).

\section{Inspiration}

Mother Teresa was deeply inspired by her parents, Nikola and Drana Bojaxhiu. Nikola was an outgoing individual and always welcomed anyone who visited his home regardless of social class. He instructed his wife, Drana to feed every poor person who visited their house. Even after Nikola’s passing, they continued this practice of providing help to the indigent and elderly. Drana laid the foundation for her daughter's later work through her own actions of love, care and sacrifice: feeding and providing medical aid to the poor, sewing clothes for less fortunate children, and continuing to care for the six children of a poor widow after her passing away. Mother Teresa used to accompany her mother during these social service activities and as a result, learned the lessons of love in action. Her mother always inspired her to do everything for God, and advised her "when you do it, do it silently”. It was at this time, Mother Teresa became inspired to do something for the 'poorest of the poor' (Kathryn, 1997). 


\section{Influence}

Mother Teresa was a true social entrepreneur in that she always worked towards social well being and creating social value. She took the spiritual path, helping the poor, diseased and needy. She strongly believed that whatever she was doing, it was for God; hence, it should be purely selfless and unconditional. Additionally, she spread the message of love to everyone, which inspired others to join her mission of helping the 'poorest of the poor'. There was sincere commitment, spirituality and selfless devotion in her service for the poor which quickly gained recognition from the people and government officials of India who decided to assist in her noble cause to reduce the suffering of the poor and the sick. Uniquely charismatic, Mother Teresa showed unconditional devotion to the higher cause of helping and loving the poor that inspired others to follow her footsteps. Like a true social entrepreneur, she improved and gave meaning to life for those at the bottom of the pyramid (Dees, 1998; Fruchterman, 2011)

\section{Innovation}

Mother Teresa was a young girl of 18 years when she left her home to become a missionary. She strongly believed that this way she could spread the love of Christ. Her charisma and message of love spread across the globe. She inspired millions of hearts through understanding and trust, motivated her followers to follow her footsteps by giving up worldly pleasures and finding peace and self-actualization in the act of serving the poor, needy, diseased, homeless and dejected. This way of inspiring followers is a 
typical characteristic of a transformational leader (Avolio \& Bass, 1994). She adopted a unique way of inspiring others. She valued every individual as a distinct human being who mattered to her and always said, "I believe in person to person contact. Everyone is Christ for me and since there is only one Jesus, the person I am meeting is the one person in the world at that moment” (Kathryn, 1997). She did everything in the name of God and treated every human being as a gift from God. She was a true innovator and a social entrepreneur in the sense that she practiced what she preached and was not bothered by resource limitations, took bold steps to help the poor and was always engaging her followers to adapt and learn (Dees, 1998). Through her simplicity, she instilled a deep sense of love, trust, total surrender and cheerfulness to the cause of charity or God's work (as she named it) in every heart she came across, representing Bass’s idealized influence (Bass, 1997). As her experience as a social entrepreneur grew, her influence as a transformational leader also grew at the same pace.

\section{Implementation}

Mother Teresa has followers all across the globe. Even those influential people who are not part of her Missionaries of Charity are great admirers of her devotion for helping the poor. This can easily be seen from the expansion of her efforts over the years. Mother Teresa's very first effort to care and love the uncared and unloved started in the year 1948 as an open-air school in a slum in Kolkata. Now it has become a large organization,

funded and supported by various governments, organizations and prominent people 
across the globe and has been running successfully following the very same path of spreading love and smiles for more than 60 years with more than 600 missions globally (Slavicek, 2007). Mother Teresa, until her last years, widely travelled across all the branches of Missionaries of Charity to encourage her followers. "When the telephone calls came in the night from her sisters throughout the world, it was still she who went to answer them” (Kathryn, 1997). This depicted her strong transformational leadership skills as characterized by Bass (1998) as instilling pride and gaining trust by giving personal attention, advice and coaching to the followers. She influenced every heart with her charismatic personality and inspired them to transcend their self interests for the social good (Williams, 2003).

\section{Mahatma Gandhi}

Probably no one would argue about the fact that Gandhi was one of the most innovative social entrepreneurs that ever lived on earth. Einstein said this, "Generations to come will scarce believe that such a one as this ever in flesh and blood walked upon this earth.," on the occasion of Gandhi's 70th birthday (Einstein, 1950). Gandhi passionately believed in his principles and was willing to die standing against injustice. He once famously said, "There are many causes I am willing to die for. There is not a single one I am willing to kill for” (Gandhi, 1957). His adherence to nonviolence is second to none. 


\section{Inspiration}

Gandhi was motivated by his deep desire for universal justice and freedom. He was inspired by his belief in his ability to effect social transformation in India. He loved harmony and balance and never took extreme positions on any issues unless they pertained to justice and fairness. Even with the British, Gandhi was very fair and balanced; this is exemplified by the fact that he supported Britain in their war efforts during the Second World War. His decisions and actions always took the sufferings of the poor into account. He found inspiration in being able to help the poor and fighting against injustice. His ultimate goal was social development through freedom and justice and his thoughts and actions transcended caste differences, ethnicities, states and nations. Like a transformational leader he had always helped his followers focus on larger spiritual goals rather than immediate selfish ones.

\section{Influence}

Gandhi influenced people through the genuineness of his actions and purity of his thoughts and philosophies. He lead by example and was always willing to take the first blow from the British police or army in a civil disobedience march. Even though Gandhi was not a great speaker he influenced and mobilized the masses through the meaning of his message. Gandhi enjoyed a great degree of referent power through his charisma and ethics of absolute non-violence. Like a great transformational leader, he modeled moral 
values himself and raised the ethical bar of morality for his followers (Bass, 1985; Burns, 1978; Howell \& Avolio, 1992; Zhu, et.al., 2011). Bass and Steidlmeier (1999) noted "it is striking that out of global diversity, Christian Martin Luther King found inspiration in Hindu Mahatma Gandhi’s philosophy of non-violence.” Gandhi was definitely a role model to his followers, thus showing idealized influence (Bass, 1998).

\section{Innovation}

Satyagraha is the best example of Gandhi's innovative approach to solving difficult social problems. During the British occupation of India many Indian freedom fighters were of the view that armed resistance may be the only way forward to gaining home rule for India. At the same time most of them were aware of the fact that no armed resistance can stand up against the mighty British army. Gandhi's idea of noncooperation or Satyagraha had overcome multiple problems compared to armed resistance, such as violence and resource constraints. Noncooperation needs almost no funding and moreover, it is forceful and sustainable. According to Dees (1998), Gandhi depicted the true characteristics of a social entrepreneur by adopting some innovative approaches like Satyagrah, noncooperation and the Khadi movement. According to Bornstein (2004), Gandhi acted as a true social entrepreneur by acting as a social change agent and recognizing the right opportunities to serve the mission.

\section{Implementation}


Gandhi was a karma yogi, meaning, he perfected and purified himself through selfless actions, a unique characteristic of a transformational leader. His idealism and perfectionism gave him tremendous courage to fight the mighty British purely through nonviolent means. Gandhi was a master in being diplomatic without compromising with his principles. Gandhi consistently and emphatically encouraged his followers to follow his path of nonviolence by pointing them to the spiritual superiority of his approach. This clearly depicted the strong transformational leadership qualities of Gandhi which kept on strengthening with time as his act of social entrepreneurship gained recognition among the Indian society.

\section{Wangari Maathai}

Depending on where you are from, you may or may not know the woman that has transformed our planet and its people by planting trees, many people in Kenya know her simply as 'the tree woman,' but her real name is Wangari Maathai. In 2004, she won the Noble Peace Prize for her “contributions to sustainable development, democracy and peace,” (Noble Peace Prize, 2004). Dr. Wangari Maathai started, led and managed the Green Belt Movement in 1977 until her death in 2011, working with women to improve their livelihoods by increasing their access to resources like firewood for cooking and clean water. She became a great advocate for better management of natural resources and for sustainability, equity, and justice (Green Belt Movement, 2011). 


\section{Inspiration}

Wangari Maathai was born in the central highlands of the, then British Kingdom colony, Kenya on April 1, 1941. Having a family that depended on agriculture to survive, Maathai was well aware of the interconnectedness of nature and people (Maathai, 2006). She had a thirst for knowledge and a curiosity to search for understanding which made her excel in the classroom. Besides being a good student throughout her academic career, she was also the first woman in East and Central Africa to earn a Ph.D. (Maathai, 2006). During the time when her husband was associated with the Kenyan Parliament, she became overwhelmingly aware of the poor living conditions of the rural people. The women had to walk farther distances for firewood and clean water; their children were malnourished and there was severe problem of soil erosion. Her first instinct, as a studier of ecology, was to plant trees for obvious benefits: trees provide shade, prevent soil erosion, supply firewood, building materials, and produce nutritious fruits. Her inspiration was sparked from her own childhood and the bounty of nature which made her realize that how deforestation has changed the landscape of her native place over the years making life of the poor miserable. She felt compelled to offer a better way for these rural people to live and save the environment from destruction. Her vision to save nature from commercial plantations grew into an innovative social entrepreneurial movement whose actions could be seen and felt around the world; literally transforming the landscape and the lives of the marginalized people of Kenya. Through her transformative leadership, she propelled her followers to stand up for a democracy which valued its people as well as its environment, recognizing that there must be harmony between the 
two in order to achieve peace in the world. "The women of the Green Belt Movement have learned about the causes and the symptoms of environmental degradation. They have begun to appreciate that they, rather than their government, ought to be the custodians of the environment," she quoted in a speech at Radcliffe College, Harvard University, USA, 1994 (Green Belt Movement). In this way, she was able to transform a social problem into a value adding solution for the social good.

\section{Influence}

Leading by example, Maathai pursued a profession in research and academia. She taught at the University of Nairobi and became the first woman to hold the positions of Senior Lecturer to Chair of Anatomy Department and then Associate Professor (Green Belt Movement). Throughout her time, Maathai campaigned for equal benefits for women working at the University and became increasingly politically active as she became environmentally and socially aware that environmental degradation and mismanagement

of its resources was at the root of Kenya’s problems (Mjøs, 2004). As per Bass’ (1998) transformational leader definition, she developed others, however, this development improved the lives of poor through greater emotional meaning and economics, which we know from Dees (1998) and Fruchterman (2011) to be the inspirational drivers to a social entrepreneur. She continued to develop her followers through individualized attention and (Bass, 1999) skill training and coaching (Green Belt Movement, 2011) which influenced the followers towards self-actualization (Burns, 1978), and reinforced that all 
followers are agents of change (Dees, 1998). She created a strong network of key staff and supporters who were convinced of the social value of her mission (Austin, Stevenson, Wei-Skillern, 2006). "It is evident that many wars are fought over resources which are now becoming increasingly scarce. If we conserved our resources better, fighting over them would not then occur...so, protecting the global environment is directly related to securing peace...those of us who understand the complex concept of the environment have the burden to act. We must not tire, we must not give up, and we must persist”, Maathai said after she was nominated for the Nobel peace prize in 2004 (The Green Belt Movement). This intellectual stimulation and increased self-worth instilled pride in her followers (Bass, 1998) which further encouraged them to bring on more community support to be successful. She always said, "You cannot protect the environment unless you empower people, you inform them, and you help them understand that these resources are their own, that they must protect them” (Green Belt Movement). In 2002, Wangari Maathai was elected in to the Kenyan parliament and, having a legitimate voice in the formal arena of policymaking, was able to widely broadcast the purpose and expectations of her Green Belt Movement. Through her social entrepreneurial innovative venture she demonstrated true qualities of a transformational leader which kept on polishing during the course of time as more number of women, children and even men started getting associated with her movement.

\section{Innovation}


The business model of community-based tree planting of the Green Belt Movement was to pay people for planting trees and they get paid again when they sell the trees. The biggest advantage of this model was that this made the caretaking the responsibility of the people and in the process as the plants grew, the land healed, the water level rose and the people could sell or eat the fruit from their trees, and sell or use the wood for firewood. With this additional revenue stream the profit could be reinvested for more trees, purchasing of honeybees or even goats that would then generate more resources. Maathai's belief that it was necessary to teach the women the skills necessary to plant and nourish the nurseries of native and medicinal trees stimulated the intellectual and reverberated throughout the community and soon men in the families of the women were joining the mission and bringing in their highly valued skills of literacy. This was an extremely innovative process of building local capacity through civic education, increased skill building and through organization that offered self-help to all its members and the community. For Wangari Maathai, every person was seen as someone who could add value to her mission.

\section{Implementation}

Maathai was able to build a movement that should be seen as a social entrepreneurial empire with a clearly defined purpose of social well being. The planted trees provided shade, food, and fuel; healed the scarred landscapes of Kenya and acted as means of economic prosperity to the poor. All of these activities were supported by a strong 
grassroots network (Alvord, Brown, Letts, 2003). Maathai's bold actions have led to over 47 million trees having been planted to date. According to the Green Belt Movement's website, "the group seeks to create experiential learning opportunities through the development of an empowerment center for young Africans. Through nurturing a new culture of entrepreneurship, GBMI will unleash the creativity and confidence necessary for our youth to achieve their potential. GBMI aims to: Develop a model empowerment program based on GBM's current civic and environmental programs and conduct research into similar experiential learning programs around the world. Design and build an Empowerment Center for youth, particularly women and girls, in Kenya that uses the model program described above. Increase the impact of our programs through inviting youth from across Africa to participate. Develop institutional partnerships to expand the concept in Kenya and throughout the world.” (The Green Belt Movement, 2011). She exemplifies a transformational leader whose vision reached beyond her own goals and built up those who followed her. She led a successful social entrepreneurial endeavor that innovated and engaged its stakeholders. Her followers were deeply impressed with her persistence; even though she was repeatedly beaten, jailed and harassed, she never gave up and set an example for her followers.

Maathai was an exemplar of distinction in creatively mitigating community problems that enacted novel entrepreneurial growth that serve to transform the people of the community and the leaders with a focus on a network of collaborators. 


\section{Social Entrepreneuring as Transformational Leading}

There is a real need for developing effective leaders in all walks of life. One of the goals of this study is to see how we can use social entrepreneuring as a way to develop transformational leaders. Public, private, charitable and religious organizations, all face with the challenge of identifying and developing leaders who are visionaries, ethical and able to build sustainable organizations (George, 2003). In addition, it is generally expected that good leaders develop followers into leaders. Burns (1979) argued that one of the most important characteristics of a transforming leader is his or her ability to instill leadership qualities in followers. Based on the similarities we have uncovered between social entrepreneurship and transformational leadership, we argue that social entrepreneuring could be an effective way to develop transformational leaders.

According to Bass (1999) “Transformational leadership refers to the leader moving the follower beyond immediate self-interests through idealized influence (charisma), inspiration, intellectual stimulation, or individualized consideration.” Unlike for-profit entrepreneurs, social entrepreneurs' ability to influence others is mainly limited to their own charisma because no other sanctions or rewards are available to them. Social entrepreneuring will also help individuals learn how to motivate others to achieve greater good even when materialistic benefits are nonexistent. There could also be situations in the regime of social entrepreneurship when participants have to sacrifice their time, energy and other materialistic resources for social good. Only meaningful return, perhaps the most important one, could be ones opportunity to self-actualize (Bass, 1999). 
Practicing idealized influence and perfecting the act of using it effectively for achieving super ordinate goals is in fact learning transformational leadership through the principle of learning by doing (Hilgard, 1956; Anzai and Simon, 1979). The context of social entrepreneurship also affords ample opportunities to learn other transformational leadership skills such as intellectual stimulation and individualized consideration.

\section{Implications for Social Entrepreneurs, Practitioners and Students}

In this paper we have shown that social entrepreneurship is indeed transformational leadership in action. Both social entrepreneurs and transformational leaders are motivated by superordinate goals rather than short term personal gains and this similarity in their theory of life has major implications for social entrepreneurs, leadership development trainers and coaches, senior executives entrusted with succession planning and developing a pipeline of future leaders within their organizations and students trying to learn leadership skills for working in both for-profit and not-for-profit organizations.

\section{For Social Entrepreneurs}

Entrepreneurs in general are passionate about creating something new, they have high risk taking propensities, and they get excited when they are able to innovate. However, social entrepreneurs could be different from for-profit entrepreneurs in their theory of life. Their values and beliefs about human nature, the kind of society they envision and how they can achieve it, all could be different from that of for-profit entrepreneurs. In this paper, we have shown that social entrepreneurs' theory of life is more in line with that of 
transformational leaders. Further, we argued that, when required, successful social entrepreneurs are well positioned to show transformational leadership skills.

\section{For Leadership Development Trainers and Senior Executives}

In general, modern organizations are more transactional than transformational. Organizations typically seem to persue short term goals and consider their employees as expendable resources rather than the most important stakeholders. In this paper, we argue that this type of organizational environment is not conducive for grooming transformational leaders. We have suggested that encouraging young and upcoming managers to participate in social entrepreneurial activities could be an effective way to instill transformational leadership skills. When designing leadership development workshops, it is important to include teaching materials and case studies related to social entrepreneurship to develop transformational leadership skills.

\section{For Students}

Based on our findings described in this paper, students can effectively develop transformational leadership skills by participating in social entrepreneurial ventures. This approach is especially useful to students because finding responsible positions in a social venture is relatively easier than finding it in for profit organization. In addition, as

mentioned earlier, social ventures are the ideal playground for practicing transformational leadership skills.

\section{Conclusion}


We have developed a framework to compare the content and process of social entrepreneurship and transformational leadership. We have validated our framework by looking at the lives of three social entrepreneur-turned-transformational leaders. We have also indicated the possibility of using social entrepreneuring as a transformational leadership development intervention.

\section{Acknowledgements}

We thank Joanna Fowler and Craig Macaulay for helpful suggestions with the content and style of this paper.

\section{Bibliography}

Alvord, S. H., L.D. Brown and C.S. Letts (2003). 'Social Entrepreneurship Leadership That Facilitates Societal Transformation - An Exploratory Study', Center for Public Leadership Working Papers: Harvard University Press, p.p. 135-159.

Alvord, S. H., L. D. Brown and C.W. Letts (2004). 'Social Entrepreneurship and Societal Transformation', Journal of Applied Behavioral Science, 40 (3), 260-282.

Antonakis, J., C.A. Schriesheim, J.A. Donovan, K. Gopalakrishna-Pillai, E. Pellegrini and J.L. Rossomme (2004b). ‘Methods for studying leadership', in J. Antonakis, A. T. Cianciolo, \& R. J. Sternberg (Eds.), The nature of leadership, Greenwich, CT: Sage, pp. $48-70$. 
AOM- ENT Division. (n.d.). ‘Academy of Management Learning \& Education Call for Papers 2012 special issue,' available at http://www.aom.pace.edu/amle/2012SI_CFP.asp (accessed 17 October 2011).

Anzai, Y. and H.A. Simon (1979). 'The Theory of Learning by Doing', Psychological Review, 86 (2), 124-140.

Austin, J., H. Stevenson and J. Wei-Skillern (2006). 'Social and Commercial Entrepreneurship: Same, Different, or Both?’, Entrepreneurship Theory \& Practice: Baylor University, 1, 1-23.

Avolio, B. J., J. J. Sosik and D. I. Jung (2003). 'Leadership models, methods, and applications', in W. C. Borman \& D. R. Ilgen (Eds.), Handbook of Psychology: Industrial and Organizational Psychology, New York: John Wiley and Sons, 12, 277-307.

Avolio, B. J., and B. M. Bass (1994). 'Improving organizational effectiveness through transformational leadership', Thousand Oaks, CA: Sage Publications, Inc.

Baker, Britt. (2010, August 27). 'The Ultimate Guide to Social Enterprise Conferences', available at http://www.greenmarketing.tv/2010/08/27/ultimate-guide-social-enterpriseconferences (accessed 16 October 2011).

Bass, B. M. (1985). 'Leadership and performance beyond expectations', New York: The Free Press. 
Bass, B. (1998). ‘Transformational leadership: industrial, military, and educational impact’. New Jersey: Lawrence Erlbaum Associates Ltd.

Bass, B. M. (1999). 'Two Decades of Research and Development in Transformational Leadership', European J. of Work and Org. Psychology, 8 (1), 9-32.

Bass, B. M. and P. Steidlmeier (1999). 'Ethics, character, and authentic transformational leadership behavior', The Leadership Quarterly, 10 (2), 181-217.

Bornstein, D. (1998). 'Changing the world on a shoestring', Atlantic Monthly, 281(1), 3439.

Bornstein, D. (2004). How to change the World: Social Entrepreneurs and the power of new ideas, New York: Oxford University Press.

Boschee, J. (1998). 'Merging mission and money: A board member’s guide to social entrepreneurship’, available at http://128.121.204.224/pdfs/MergingMission.pdf (accessed 20 October 2011).

Burns, J. M. (1978). ‘Leadership’, New York: Harper and Row.

Byrne, J. (2010, August 13). 'Social Entrepreneurship: The Best Schools \& Programs’, available at http://poetsandquants.com/2010/08/13/social-entrepreneurship-the-bestschools-programs/8 (accessed 17 October 2011).

Cogliser, C. C. and K. H. Brigham (2004). ‘The intersection of leadership and entrepreneurship: Mutual lessons to be learned', The Leadership Quarterly, 15, 771-799. 
Colby, S., N. Stone and P. Carttar (2004). 'Zeroing in on impact', Stanford Social Innovation Review, 2, 24-33.

Conger, J.A. and R.N. Kanungo (1998). ‘Charismatic leadership in organizations’. Thousand Oaks, CA: Sage.

Cydebot (Ed.). (2011, Oct 09). 'Mother Teresa’, available at http://en.wikipedia.org/w/index.php?title=Mother_Teresa\&oldid=454743582 (accessed 11 October 2011).

Davidsson, P. (2005). 'Researching Entrepreneurship’, United States of America: Springer.

Dees, J.G. (1998). 'The Meaning of "Social Entrepreneurship"', Stanford University: Draft Report for the Kauffman Center for Entrepreneurial Leadership, 6 pp.

Dees, J.G. (1998). ‘Enterprising Nonprofits’, Harvard Business Review. JanuaryFebruary 1998, 55-67.

Desmond, E. (1989, Dec 04). 'Interview with Mother Teresa: A Pencil In the Hand Of God', Time Magazine, p.p. 2.

Drayton, W. (2002). 'The citizen sector: Becoming as entrepreneurial and competitive as business', California Management Review, 44 (3), 120-132.

Drucker, P.F. (1985). 'Innovation and entrepreneurship: practice and principles’, Albuquerque, N.M.: Newman Communications Corp. 
Einstein archive (1950). 'Out of My Later Years’, 32-601.

Ensley, M.D., K. M. Hmieleski, and C. L. Pearce (2006). 'The importance of vertical and shared leadership within new venture top management teams: Implications for the performance of startups', The Leadership Quarterly, 17, 217-231.

Eyal, O. and Kark, R. (2004). 'How do Transformational Leaders Transform Organizations? A Study of the Relationship between Leadership and Entrepreneurship’, Leadership and Policy in Schools, 3, (3), 211-235.

Frucheterman, J. (2011). 'For Love or Lucre’, Standford Social Innovation Review, 4247.

Gandhi, M. (1957). ‘An autobiography: The story of my experiments with truth’ (Reprint ed.): Beacon Press.

George, W. (2003). 'Authentic leadership: Rediscovering the secrets to creating lasting value’, San Francisco: Jossey-Bass.

'Green Belt Movement Goals’, available at www.greenbeltmovement.org (19 October 2011).

Guttenplan, D. (2011, January 23). 'Business Schools with a Social Appeal', New York Times, p. Education.

Hart, M. M., H. H. Stevenson and J. Dial (1996). ‘Entrepreneurship: A definition’ revisited in W. Bygrave (Ed.), Frontiers of Entrepreneurship 1995: Proceedings of 
the15th Annual Entrepreneurship Research Conference, Babson Park, MA: Babson College, 75-89.

'Social Entrepreneurship Fellowship’, available at

http://www.hbs.edu/socialenterprise/your-career/social-entrepreneurship-fellowship (accessed 16 October 2011).

Henton, D., J. Melville and K. Walesh (1997). 'The age of civic entrepreneur: restoring civil society and building economic community’, National Civic Review, 86 (2), 149-156.

Hilgard, E. R. (1956). 'Theories of Learning', 2nd ed., New York: Appleton-CenturyCrofts.

Johnson, D. (2001) 'What is innovation and entrepreneurship? Lessons for larger organizations', Industrial and Commercial Training, 33 (4), 135 - 140

Kathryn, S. (1997). Mother Teresa: An Authorized Biography (Kindle ed.). San Francisco: HarperCollins.

Frängsmyr, Tore (2005).. 'The Nobel Prizes 2004', Les Prix Nobel, Stockholm: Nobel Foundation Publications.

Low, M. B. and I.C. MacMillan (1988). 'Entrepreneurship: Past research and future challenges’, Journal of Management, 14 (2), 139-161. 
Maathai, Wangari (2004). 'Nobel Lecture’ available at

http://www.nobelprize.org/nobel_prizes/peace/laureates/2004/maathai-lecture-text.html (accessed 10 October 2011).

Maathai, Wangari (2007). Wangari Maathai, Unbowed : A Memoir, London: William Heinemann.

Mair, J. and I. Marti (2004). 'Social Entrepreneurship research: A source of explanation, prediction and delight', IESE Business School- University of Navarra Working paper, WP No. 546.

McDaniel, B.A. (2000). ‘A survey on entrepreneurship and innovation', The Social Science Journal, 37, (2), 277-284.

'Missionaries of Charity Brothers', available at http://www.mcbrothers.org/history.htm (accessed 10 October 2011).

Mjøs, Ole Danbolt (2004), ‘Award Ceremony Speech’ available at http://www.nobelprize.org/nobel_prizes/peace/laureates/2004/presentation-speech.html (accessed 10 October 2011).

Peredo, A. M. and M. McLean (2006). 'Social Entrepreneurship: A critical review of the concept', The Journal of World Business, 41(1), 56-65. 
Pillai, R. and E.A. Williams (2003). ‘Transformational leadership, self-efficacy, group cohesiveness, commitment, and performance', Journal of Organizational Change Management, 17 (2), 144-159.

'Registered Non Profit Organizations by Country’ available at http://nccsdataweb.urban.org/tablewiz/tw_bmf.php (accessed 16 October 2011).

Reis, T. (1999). 'Unleashing the New Resources and Entrepreneurship for the Common Good: a Scan, Synthesis and Scenario for Action. Battle Creek, MI: W. K. Kellogg Foundation: 27 pp.

Roberts, N.C. (1985). ‘Transforming Leadership; A process of collective action', Human Relations, 38, 1023-1046.

Sahlman, W.A. (1996) 'Some thoughts on business plans' in W.A. Sahlman, H.

Stevenson, M.J. Roberts, \& A.V. Bhide (Eds), The entrepreneurial venture, Boston: Harvard Business School Press, pp. 138-176.

Schumpeter, J. (1934). The theory of economic development: an inquiry into profits, capital, interest, and the business cycle, Cambridge: Harvard University Press.

Schumpeter, J. (1942). Capitalism, Socialism, and Democracy, 14. New York: Harper and Row.

Shane, S. and S. Venkataraman (2000). 'The promise of entrepreneurship as a field of research', Academy of Management Review, 25, 217-226. 
Slavicek, Louise (2007). Mother Teresa, New York: Infobase Publishing, 90-91.

Thompson, J., G. Alvy and A. Less (2000). 'Social Entrepreneurship: A new look at the people and the potential', Management Decision, 38 (5), 328-338.

US News. (2011, Aug 12), 'Social Entrepreneurship and the M.B.A' available at http://www.usnews.com/education/blogs/MBA-admissions-strictlybusiness/2011/08/12/social-entrepreneurship-and-the-mba (accessed 10 October 2011).

Vecchio, R. P. (2003). ‘Entrepreneurship and leadership: Common trends and common threads', Human Resource Management Review, 13 (2), 303-328.

Venkataraman, S. (1997). 'The distinctive domain of entrepreneurship research: An editor's perspective’ in J. Katz \& R. Brockhaus (Eds.), Advances in entrepreneurship, firm emergence, and growth, Greenwich, CT: JAI Press, 3, 119-138.

Williams, J. I. (2003). ‘Mother Teresas Style of Leadership', Leadership in HRD, Indiana State University.

Wortman, M. S. (1987). 'Entrepreneurship: An integrating typology and evaluation of the empirical research in the field', Journal of Management, 13 (2), 259-279.

Yukl, G. (1999b). ‘An evaluative essay on current conceptions of effective leadership’, European Journal of Work and Organizational Psychology, 8 (1), 33-48.

Yukl, G. A. (2002). Leadership in organizations (5th ed.). Upper Saddle River, NJ: Prentice Hall. 
Zhu,W., R. E. Riggio, B. J. Avolio and J. J. Sosik (2011). 'The Effect of Leadership on Follower Moral Identity: Does Transformational/Transactional Style Make a Difference?', Journal of Leadership \& Organizational Studies, 18 (2), 150-163. 